\title{
Congenital hyperinsulinaemic hypoglycaemia- Genetically confirmed case series from a single centre
}

\author{
N Atapattu ${ }^{1}$, U Kollurage ${ }^{1}$, A K Lamahewage ${ }^{1}$, K S H De Silva ${ }^{1,2}$
}

Ceylon Medical Journal 2017; 62:193-198

DOI: http://doi.org/10.4038/cmj.v62i3.8524

\section{Introduction}

Congenital hyperinsulinaemic hypoglycaemia (CHI) associated with recurrent hypoglycaemia is a genetic disorder associated with inappropriate secretion of insulin from pancreatic beta cells [1,2]. Excess insulin production inhibit gluconeogenesis, glycogenolysis as well as ketone body production resulting in substrate deficiency to brain cells [3]. The incidence of CHI vary from 1 in 35,000-40,000 in the general population to 1 in 2500 in countries where consanguinity is high [4]. CHI has heterogeneous clinical presentation, response to therapy and molecular basis. The patients usually present before the first year of life with seizures or symptoms of hypoglycaemia like drowsiness, sweating or pallor.

Early recognition and meticulous management is important to prevent hypoglycaemia induced poor neurodevelopmental outcome. In this condition, the glucose requirement to maintain blood sugar levels above $3 \mathrm{mmol} / \mathrm{l}$ could be as high as 17 $\mathrm{mg} / \mathrm{kg} / \mathrm{min}[5]$.

Mutations in nine genes involved in insulin secretion are identified as causing this disorder [6]. Only $45-50 \%$ of patients have a genetic defect, in the rest the genetic aetiology has not yet been identified [7].

We present the first case series of genetically confirmed CHI in Sri Lanka from a specialized unit which presented over a 5-year duration. The genetic tests were done at the Molecular Diagnostics Laboratory at Exeter, United Kingdom. These tests were done free of charge. Consent was obtained from the parents for genetic testing and publication.

\section{Case 1}

Baby girl born to non-consanguineous parents with a birth weight of $4.3 \mathrm{~kg}$. She developed hypoglycaemic seizures within the first 24 hours of birth. She required $15 \mathrm{mg} / \mathrm{kg} / \mathrm{min}$ of glucose to maintain blood sugar levels and ketone bodies were negative with hypoglycaemia. Insulin level was 50 microIU/1 when her blood sugar was $35 \mathrm{mg} / \mathrm{dl}$ confirming hyperinsulinaemia. Intensive medical therapy with intravenous glucose and diazoxide, failing which octreotide was commenced. She required glucogan injections intermittently to maintain normoglycaemia. With maximum medical therapy, she continued to require large doses of dextrose and required near total pancreatectomy at the age of two and a half months.

Postoperatively she required small doses of octreotide for 2 months. Early intervention was started while she was in the ward as recurrent hypoglycaemia is known to result in neurodevelopmental abnormalities. Subsequently she underwent genetic tests with the help of Exeter Molecular Laboratory in the United Kingdom and she was found to have homozygous novel ABCC8 missense mutation, p.R504P. Both parents were heterozygous for this novel mutation. She currently has normal development and does not have any complications of pancreatectomy such as diabetes mellitus or pancreatic enzyme deficiency.

\section{Case 2}

Baby girl born to non-consanguineous parents with a birth weight of $2.75 \mathrm{~kg}$. According to her parents her postnatal period was uneventful and she was exclusively breast fed for 6 months. At 6 months of age she presented with an afebrile

${ }^{1}$ Lady Ridgeway Hospital, Colombo and ${ }^{2}$ Department of Paediatrics, Faculty of Medicine, University of Colombo, Sri Lanka.

Correspondence: NA, E-mail: < navodaa@gmail.com >. Received 20 March 2017 and revised version accepted 24 July 2017. 
convulsion in the morning which was treated as a seizure disorder. When she presented with recurrent early morning seizures, hypoglycaemia was detected and she was referred for specialized care. Her insulin level at the time of hypoglycaemia was 20.5 microIU/L She responded to diazoxide therapy. A known genetic mutation was not identified. An uninterrupted supply of diazoxide was not possible at times and she got breakthrough seizures with hypoglycaemia. During the last 6 months she was able to obtain medicine at appropriate doses and she is symptom free. However, she has development delay due to recurrent hypoglycaemia.

\section{Case 3}

This child was born to non-consanguineous parents after treatment for 10 years of subfertility. It was a twin pregnancy and the male sibling was unaffected. The babies were born at 32 weeks and the index patient who is the $2^{\text {nd }}$ of the twins had a birth weight of $1.8 \mathrm{~kg}$. She presented with hypoglycaemia from the $2^{\text {nd }}$ day of life. She did not respond to maximum doses of diazoxide or octreotide and required a near total pancreatectomy at the chronological age of 2 months. She was heterozygous for an ABCC8 missense mutation, p.E501K. Her mother and sibling were unaffected and father had the same heterozygous mutation which could indicate focal hyperinsulinaemia. The pancreatic tissue which was examined did not show reduction in the maternal allele for markers spanning from the chromosome $11 \mathrm{p} 15.5$ - $11 \mathrm{p} 15.1$ region which includes the IGF2, H19 and ABCC8 gene. The diagnosis of focal hyperinsulinism was not confirmed and it was not clear whether the tissue sample was predominantly from the normal margin of the lesion. After pancreatectomy she required octreotide to maintain normoglycaemia.

\section{Case 4}

A baby girl born to non-consanguineous parents with a birth weight of $4.3 \mathrm{~kg}$ was referred due to persistent hypoglycaemia. Gestational diabetes was excluded in the mother. She was treated with diazoxide for 2 weeks and discharged from the neonatal unit. She presented with convulsions at 6 months of age and was treated for a seizure disorder with anti-epileptics. The baby was referred for specialized management. She had insulin of 12 microIU/L while hypoglycaemic. She responded to diazoxide. She was heterozygous for a novel ABCC8 missense mutation, p.A554Vand so was her father. Facilities were not available to do 18F-DOPA PETCT scan. After 2 years of treatment the diazoxide was tailed off and stopped. Her fasting tolerance was checked and it was $>8$ hours. As there was no requirement to keep a baby fasting for more than 8 hours, the fasting tolerance test was discontinued. Child had initial developmental delay But she is catching up after treatment.

\section{Case 5}

A term baby boy born to nonconsanguineous parents with a birth weight of 2.52 $\mathrm{kg}$. He had refractory hypoglycaemic episodes and was sent for specialised care. His insulin level was 93.5 microIU/L. He required octreotide for glucose control. During the initial period, high glucose concentrations were required through central intravenous access. He developed severe sepsis and deep vein thrombosis due to the central line which had to be removed. He developed recurrent hypoglycaemic episodes due to lack of intravenous dextrose. He was heterozygous for a KCNJ11 frameshift mutation, p.Gly132fs. His mother did not have the same mutation. It was not possible to get father's sample as he left the family while the baby was in the hospital. Even though the baby responded to octreotide he became blind and microcephalic with spastic quadriplegic cerebral palsy. $\mathrm{He}$ is receiving occupational and physiotherapy at present.

\section{Case 6}

This is the younger sibling of case 1 . She had a birth weight of $3.7 \mathrm{~kg}$. She was found to have hypoglycaemia during the first 24 hours. Because of the family history the baby was started on intravenous dextrose and subcutaneous octreotide and transferred for specialized care. Hypoglycaemia responded to frequent feeds and octreotide injections. Over a period of 2 months we could tail off octreotide and the child became normoglycaemic. This baby had the same mutation as her elder sibling, however she did not require pancreatectomy or long term medical management. This highlights the marked heterogeneity in this condition even with the same genetic mutation.

\section{Case 7}

A baby girl born to a non-consanguineous family was referred due to refectory severe hypoglycaemia from day 1 of life. She was initially managed with diazoxide and octreotide but had poor response. She was heterozygous for an ABCC8 nonsense mutation, p.Q374. Her father had the same heterozygous mutation. 18F-DOPA PET-CT scan was not possible and the reference laboratory suggested starting her on a newly introduced drug everolimus. She responded well and the need of 
octreotide reduced. However, she got admitted with an upper respiratory tract infection. She acquired a severe sepsis in the ward and succumbed to it.

\section{Case 8}

Baby girl born to non-consanguineous parents with a birth weight of $3.35 \mathrm{~kg}$ was referred due to refractory hypoglycaemia form day 2 of life. Insulin level was $2.5 \mathrm{micIU} / 1$ at the time of hypoglycaemia. She was homozygous for a KCNJ11 frameshift mutation, c.390_393dup and both parents were heterozygous. There was initial response to octreotide and at 2 months of age she underwent near total pancreatectomy due to recurrent hypoglycaemia while on maximum medical therapy. She subsequently required lower dose of octreotide to maintain normoglycaemia. At present, she has marginal development delay and has been referred for specialised follow up.

Table 1 summarises the basic characteristics of the 8 patients.

\section{Discussion}

CHI is a rare genetic condition with recurrent hypoglycaemia associated with long term neurodevelopmental sequelae if not properly managed. The eight patients referred to the unit had complete work up for neonatal hypoglycaemia as per standard protocol other than blood free fatty acid levels and organic acids which were not available.

Patients with CHI generally are macrosomic due to foetal hyperinsulinaemia. We had two patients who had birthweight more than $4 \mathrm{~kg}$. However, absence of macrosomia do not exclude $\mathrm{CHI}$.

All 8 patients presented with early onset hypoglycaemic seizures with a glucose requirement of more than $8 \mathrm{mg} / \mathrm{kg} / \mathrm{min}$ to maintain normoglycaemia. Congenital hyperinsulinaemia should be suspected when the glucose infusion rate (GIR) reaches this level [8]. Hyperinsulinaemia is biochemically confirmed when the insulin level is detectable in the presence of hypoglycaemia, absent ketone bodies, and positive glycaemic response $(>1.5 \mathrm{mmol} / \mathrm{L})$ to intramuscular glucogan. The insulin level and the severity of hypoglycaemia has no correlation, which was so in our patients too [9].

Diazoxide is the mainstay of management. A thiazide diuretic is added to prevent water retention when diazoxide is used. When the patient dose not respond to diazoxide, octreotide should be started. During this process, intravenous glucose should be continued and intramuscular glucogan is also used intermittently to maintain glucose level between 3.5-6 mmol/1 [1].
When the maximum medical management does not maintain normoglycaemia, near total pancreatectomy is done.

Recessive mutations in ABCC8 and KCNJ11 commonly result in CHI [10]. In this series five patients had mutation in ABCC8 and two patients had mutation in KCNJ 11. Only one patient did not show a known genetic mutation. The two siblings had a novel mutation in ABCC 8. We had three patients with homozygous mutation two required near total pancreatectomy. There are two histological subtypes. Diffuse form result from recessive and dominant mutations in $\mathrm{ABCC} 8$ and KCNJ11.

The focal form result from inheritance of paternal mutation in $\mathrm{ABCC} 8$ or $\mathrm{KCNJ} 11$ and somatic loss of the maternal $11 \mathrm{p}$ allele $(11 \mathrm{p} 15$.to $11 \mathrm{p} 15.5)$ involving the ABCC 8 and KCNJ11 region within the focal lesion $[11,12]$. Focal lesions require only the resection of the affected part. Diffuse disease can be managed either with long term octreotide therapy or surgery. Focal lesions can only be detected with the 18F-DOPA PET-CT scan and this facility was not available to us. One of our patients with paternally inherited heterozygous ABCC8 missense mutation,p.E501K underwent near total pancreatectomy and the tissue was sent for further analysis to look for somatic loss of the maternal $11 \mathrm{p}$ allele (11p15.to $11 \mathrm{p} 15.5)$ involving the ABCC8 and KCNJ11 region. There were no mutations detectable in the specimen and the diagnosis of focal disease was not confirmed. Even after pancreatectomy, the child required octreotide to maintain blood sugar.

Two other patients had heterozygous mutation inherited from the father. One responded to diazoxide and the second patient succumb to an infection. One patient with heterozygous mutation could not be tested further as the sample couldn't be obtained from the father. The patient was managed medically with octreotide.

The decision to do near total pancreatectomy was taken only when medical management failed. Near total pancreatectomy can give rise to insulin dependent diabetes mellitus and pancreatic exocrine insufficiency later in life [13]. The decision to do a pancreatectomy was therefore taken after with genetic tests results and response to medical therapy. Parents were counselled regarding the long term sequelae of near total pancreatectomy.

Patients with CHI need long term close follow up. Hypoglycaemia during the initial period can result in neurodevelopment disabilities later in life. These children need early intervention even before we see problems in the developmental milestones to minimize the consequences of recurrent hypoglycaemia. 
Close monitoring and follow up is needed for children who are completely cured after pancreatectomy or are still receiving medical therapy, to detect development of neurological consequences due to recurrent hypoglycaemia, late onset diabetes or pancreatic exocrine insufficiency because of surgery. Multidisciplinary care team consisting of an endocrinologist, paediatrician, surgeon, psychiatrist and geneticist is necessary for optimal care of these patients

\section{Conclusion}

This is the first ever genetically confirmed series of patients with CHI from Sri Lanka. Over a period of 5 years eightpatients were diagnosed and seven of them had the common genetic mutation known to cause CHI. With limited facilities management was extremely challenging and this cohort will receive appropriate multidisciplinary follow up.

\section{Acknowledgement}

Dr. Khalid Hussain, Sarah E Flanagan, Sian Ellard for genetic testing. Dr. Padmakanthi Wijesuriya, Dr. Pushpa Punchihewa Dr. Ramya de Silva for kind cooperation given when the patients were admitted in the ward. Dr. S Sumanasena for arranging early stimulation and follow up. Referring paediatricians Dr. S. K Arulmoli, Dr. Manohari Madarasinghe and Dr. Sriyan Perera.

\section{References}

1.Hussain K: Diagnosis and management of hyperinsulinaemic hypoglycaemia of infancy. Horm Res 2008, 69: 2-13.

2.Thomas CG Jr, Underwood LE, Carney CN, Dolcourt JL, Whitt JJ: Neonatal and infantile hypoglycemia due to insulin excess: new aspects of diagnosis and surgical management. Ann Surg 1977, 185: 505-17.

3.Hussain K, Blankenstein O, De Lonlay P, Christesen HT. Hyperinsulinaemic hypoglycaemia: Biochemical basis and the importance of maintaining normoglycaemia during management. Arch Dis Child 2007; 92: 568-70.
4. Arnoux JB, VerkarreV, Saint-Martin C, et al. Congenital hyperinsulinism: current trends in diagnosis and therapy Orphanet Journal of Rare Diseases 2011; 6: 63.

5.de Lonlay P, Fournet JC, Touati G, et al. Heterogeneity of persistent hyperinsulinemic hypoglycemia of infancy. A series of 175 cases. Eur $J$ Pediatr 2002, 161: 37-48.

6. Lord K, De León DD. Monogenic hyperinsulinemic hypoglycemia: current insights into the pathogenesis and management. Int $J$ Pediatr Endocrinol 2013; 2013: 3.

7. Flanagan SE, Kapoor RR, Hussain K: Genetics of congenital hyperinsulinemic hypoglycemia. Semin Pediatr Surg 2011; 20: 13-7.

8. Aynsley-Green A, Hussain $\mathrm{K}$, Hall $\mathrm{J}$, et al. Practical management of hyperinsulinism in infancy. Arch Dis Child Fetal Neonatal Ed 2000; 82: F98-107.

9.Palladino AA, Bennett MJ, Stanley CA. Hyperinsulinism in infancy and childhood: When an insulin level is not always enough. Clin Chem 2008; 54: 256-63.

10. Flanagan SE, Clauin S, Bellanne-Chantelot C, et al. Update of mutations in the genes encoding the pancreatic beta-cell K (ATP) channel subunits

Kir6.2 (KCNJ11) and sulfonylurea receptor 1 (ABCC8) in diabetes mellitus and hyperinsulinism. Hum Mutat 2009; 30: 170-80.

11.Verkarre V, Fournet JC, de Lonlay $\mathrm{P}$, et al. Paternal mutation of the sulfonylurea receptor (SUR1) gene and maternal loss of $11 \mathrm{p} 15$ imprinted genes lead to persistent hyperinsulinism in focal adenomatous hyperplasia. J Clin Invest 1998; 102: 1286-91.

12. Fournet JC, Mayaud $\mathrm{C}$, de Lonlay $\mathrm{P}$, et al. Unbalanced expression of $11 \mathrm{p} 15$ imprinted genes in focal forms of congenital hyperinsulinism: Association with a reduction to homozygosity of a mutation in ABCC8 or KCNJ11. Am J Pathol 2001; 158: $2177-84$

13 Leibowitz G, Glaser B, Higazi AA, Salameh M, Cerasi E, Landau H. Hyperinsulinemic

hypoglycemia of infancy (nesidioblastosis) in clinical remission: high incidence of diabetes

mellitus and persistent beta-cell dysfunction at longterm follow-up. J Clin EndocrinolMetab 1995; 80: 386-92. 
Table 1. Characteristics of the patients

\begin{tabular}{|c|c|c|c|c|c|c|c|c|c|c|}
\hline Name & Date of Birth & $\begin{array}{l}\text { Birth } \\
\text { Weig } \\
\text { ht } \\
\mathrm{kg}\end{array}$ & $\begin{array}{l}\text { Age } \\
\text { (years) }\end{array}$ & $\begin{array}{l}\text { Blood } \\
\text { sugar } \\
\mathrm{mg} / \mathrm{dl} \\
*(\text { in } \\
\text { critic } \\
\text { al } \\
\text { sampl } \\
\text { e) }\end{array}$ & $\begin{array}{l}\text { Insuli } \\
\mathrm{n} \\
\text { level } \\
\mathrm{mIU} / \\
\mathrm{ml}\end{array}$ & Genetic mutation & Treatment & Neuro development & Mother & Father \\
\hline Case 1 & $13 / 06 / 2012$ & 4.3 & 5 & 25 & 50 & $\begin{array}{l}\text { homozygous for the } \\
\text { novel ABCC8 } \\
\text { missense mutation, } \\
\text { p.R504P }\end{array}$ & $\begin{array}{l}\text { Near total } \\
\text { pancreatectomy, } \\
\text { off medication }\end{array}$ & Normal & $\begin{array}{l}\text { Heterozygous for } \\
\text { the novel ABCC } 8 \\
\text { missense mutation, } \\
\text { p.R504P }\end{array}$ & $\begin{array}{l}\text { Heterozygous for } \\
\text { the novel ABCC } 8 \\
\text { missense mutation, } \\
\text { p.R504P }\end{array}$ \\
\hline Case 2 & $11 / 02 / 2013$ & 2.75 & 4 & 25 & 20.5 & No mutation & Diazoxide & Development delay & No mutation & No mutation \\
\hline Case 3 & $28 / 07 / 2013$ & 1.8 & 4 & 39 & 12 & $\begin{array}{l}\text { Heterozygous for an } \\
\text { ABCC8 missense } \\
\text { mutation,p.E501K }\end{array}$ & $\begin{array}{l}\text { Near total } \\
\text { pancreatectomy, } \\
\text { now on } \\
\text { octreotide }\end{array}$ & $\begin{array}{l}\text { Development } \\
\text { delay, poor vision }\end{array}$ & $\begin{array}{l}\text { Microsatellite } \\
\text { analysis showed no } \\
\text { reduction in the } \\
\text { maternal allele for } \\
\text { the markers in the } \\
\text { chromosome } \\
11 \text { p15.5 - } 11 \text { p } 15.1 \\
\text { region which } \\
\text { includes the IGF2, } \\
\text { H19 and ABCC8 } \\
\text { gene. }\end{array}$ & $\begin{array}{l}\text { Heterozygous for } \\
\text { the ABCC } 8 \\
\text { missense mutation, } \\
\text { p.E501K }\end{array}$ \\
\hline Case 4 & $29 / 07 / 2013$ & 4.7 & 4 & 29 & 2.18 & $\begin{array}{l}\text { heterozygous for a } \\
\text { KCNJ11 frameshift } \\
\text { mutation, p.Gly132fs }\end{array}$ & Diazoxide & Normal & No mutation & $\begin{array}{l}\text { Heterozygous for } \\
\text { the novel ABCC } 8 \\
\text { missense mutation } \\
\text { p.A554V }\end{array}$ \\
\hline
\end{tabular}




\begin{tabular}{|c|c|c|c|c|c|c|c|c|c|c|}
\hline Case 5 & $23 / 11 / 2013$ & 2.92 & 4 & 18 & 93.5 & $\begin{array}{l}\text { Heterozygous for a } \\
\text { KCNJ11 frame shift } \\
\text { mutation, p.Gly132fs }\end{array}$ & Octerotide & $\begin{array}{l}\text { Blind, development } \\
\text { delay, } \\
\text { Microcephaly }\end{array}$ & No mutation & Unable to do \\
\hline Case 6 & $18 / 02 / 2014$ & 8 & 3 & 41 & 3.7 & $\begin{array}{l}\text { homozygous for a } \\
\text { novel ABCC } 8 \\
\text { missense mutation, } \\
\text { p.R504P }\end{array}$ & $\begin{array}{l}\text { Initially } \\
\text { required } \\
\text { Octerotide, now } \\
\text { off treatment }\end{array}$ & Normal & $\begin{array}{l}\text { heterozygous for a } \\
\text { novel ABCC } 8 \\
\text { missense mutation, } \\
\text { p.R504P }\end{array}$ & $\begin{array}{l}\text { heterozygous for a } \\
\text { novel ABCC } 8 \\
\text { missense mutation, } \\
\text { p.R504P }\end{array}$ \\
\hline Case 7 & $02 / 11 / 2014$ & 6 & deceased & 43 & 3.35 & $\begin{array}{l}\text { Heterozygous for an } \\
\text { ABCC8 nonsense } \\
\text { mutation, p.Q374 }\end{array}$ & Everolimus & & No mutation & $\begin{array}{l}\text { Heterozygous for } \\
\text { the ABCC } 8 \\
\text { nonsense mutation, } \\
\text { p,Q374 }\end{array}$ \\
\hline Case 8 & $02 / 08 / 2016$ & 2.5 & 1 & 27 & 3.5 & $\begin{array}{l}\text { Homozygous for a } \\
\text { KCNJ11 frame shift } \\
\text { mutation, } \\
\text { c.390_393dup }\end{array}$ & $\begin{array}{l}\text { Octreotide- near } \\
\text { total } \\
\text { pancreatectomy, } \\
\text { subsequent } \\
\text { octreotide }\end{array}$ & Mild delay & $\begin{array}{l}\text { Heterozygous for } \\
\text { the KCNJ11 frame } \\
\text { shift } \\
\text { mutation,c.390_393 } \\
\text { dup }\end{array}$ & $\begin{array}{l}\text { Heterozygous for } \\
\text { the KCNJ11 frame } \\
\text { shift } \\
\text { mutation,c.390_393 } \\
\text { dup }\end{array}$ \\
\hline
\end{tabular}

\section{c) (7)}

This is an open-access article distributed under the terms of the Creative Commons Attribution License, which permits unrestricted use, distribution, and reproduction in any medium, provided the original author and source are credited. 